\title{
GASTRO-INTESTINAL NEMATODES OF SOME MARINE FISHES AT PORT SAID PROVINCE
}

\author{
Nosseur M. El-Sayed*, Azza M.Raef** and Nabila M. El Masry** \\ Parasitology Dept., Fac. of Vet. Medicine, Zagazig University* \\ Animal Health Institute, Agriculture Research Center, Dokki, Giza**
}

\begin{abstract}
A total of 190 marine fishes; 128 Bull head(Cottus gobio),42Red Mullet (Mullus barbatus), 8 Dusky perch (Epinephelus gigas), 12 Sea Bass (Morone laborax) were collected from mediterranean sea area at Port Said province.The prevalence of nematodes in the examined fishes was $5.26 \%$. Bull head (Cottus gobio) and Red Mullet (Mullus barbatus) were infected with nematodes (3.12\% and $14.3 \%$ ) while, Dusky perch (Epinephelus gigas) and Sea Bass (Morone laborax) were free from infection with nematode parasites. Five species of the nematodes belonging to family Anisakidae were recovered from the examined fishes. Goezia spinulosa was detected from stomach of Bull head. Hysterothylacium reliquens, Hysterothylacium geschei, Hysterothylacium sp. and, Hysterothylacium sp. larvae were recov-ered from intestine of Red Mullet.
\end{abstract}

\section{INTRODUCTION}

Fish is considered as one of the most promising source for animal protein of high biological value due to its content of nearly all essential amino acids necessary for man, animal and birds (Harford\&Arlene (1994). Gasterointestinal nematodes of fish play an important role in determing the health status of fish, they may act either a primary source of diseases or as secondary invader to other infections (Kabata, 1985 and Elmer et al., 1989). Among the agent of fish diseases, an important position is occupied by parasitic worms which attack most body organs of fish parasitizing them as adult or larvae.Nematodes are constituting a significant 
part of the parasitic fauna of marine fishes and represent an important public health problems because fish may be a source of serious nematodes to man, for example Anisakiasis. Some species of nematodes are known to be the agent of serious fish diseases causing considerable losses in fish poulation (Moravec,1994).

Many research works at different part of the world have been done on anisakid nematodes of marine fishes,Parukhin,(1976\&1989); Eslami and Mokhayer,(1977\&1994);Deardorff and Overstreat,(1981);Lakshmi et al.,(1990); Moravec, (1994 ); Petter and Sey, (1997); Torres et al., (1998); Lymbery et al.,(2002)and Mattiucci et al.,(2003)while,Mahmoud, (1990); Raef,(1990);Abdel Rhaman,(1995) and Raef \&Abdel Wahab, (1999) work on parasites of marine fish in Egypt.

The aim of the present work is to throw the light on some parasitic nematodes of some marine fishes at Port Said province, concerning their prevalence, taxonomy and morphology.

\section{MATERIALS AND METHODS}

A total of 190 marine fish; 128 Bull head (Cottus gobio), 42 Red Mullet (Mullus barbatus), 8 Dusky perch (Epinephelus gigas), 12 Sea Bass (Morone laborax) were collected from Mediterranean sea area at Port Said province. In laboratory, the fishes were examined visually and externally for detection of various nematodes localized under host skin and cyst containing nematode larvae. The fish body cavity was opened and examined, then various organs; digestive tract, swim -bladder, liver, gall bladder, spleen and kidney were dissected and placed separately in Petri dishes with saline for individual examination by naked eye and under dissecting microscope (Moravec, 1994).

The obtained nematodes were washed in physiological saline and kept in refrigerator for killing and relaxation. The relaxed nematodes were cleared and mounted according to Navone et al.,(2000). The recovered nematodes were measured, drawn by camera lucida, photographed and identified according to Moravec, (1994) and Petter and Sey, (1997). 


\section{RESULTS}

Examination of 190 marine fishes at port said city revealed that ten $(5.26 \%)$ were infected with nematode parasites. Bull head(Cottus gobio) and Red Mullet (Mullus barbatus) were infected with nematodes (3.12 $\%)$ and $(14.3 \%)$ respectively while, Dusky perch (Epinep-helus gigas) and Sea Bass (Morone laborax) were free from nematode para-sites. The prevalence of the Goezia spinulosa and, Hysterothylacium species (Hysterothylacium reliquens, Hysterothylacium geschei, Hysterothylacium sp. and Hysterothylacium sp.larvae) were $3.12 \%$ and $14.3 \%$ respectively. Taxanomy and morphological description of the detected nematodes will be denoted as follow

\section{Order :- Ascaridida (Skrjabin et Schulz,1940)}

Superfamily :- Ascaridoidea (Railliet et Henry, 1915)

Family :- Anisakidae (Railliet et Henry, 1912)

A-Genus :- Goezia (Zeder ,1800)

Goezia spinulosa (Railliet and Henry, 1915). Fig. 1- 3

- Host : Bull head (Cottus gobio)

- Habitat : stomach

\section{DESCRIPTION OF MALE}

It is a medium sized nematode, measuring $19.0 \times 1.5 \mathrm{~mm}$. The cuticle is transversely ringed, the posterior edges of the cuticular rings are provided with minute posteriorly directed spines. The head end is provided with three flat lips,. one dorsal and two ventro-lateral.The oesophagus is muscular somewhat expanded posteriorly ends with small ventriculus and measures $0.92-1.25 \mathrm{~mm}$ long. The spicules are bent and almost equal measuring $0.83 \mathrm{~mm}$ long.

B- Genus : Hysterothylacium (Ward et Margath, 1917)

1- Hysterothylacium reliquens (Norris et Overstreet, 1975) (Fig.4-6)

-Host : Red Mullet (Mullus barbatus)

-Habitat : intestine 


\section{DESCRIPTION}

Large whitish nematode with body tapering at both ends. The lateral alae is very thin, barely visible at the base of lips and become more apparent below lips. The head is provided with three lips and three inter-labia. The dorsal lip is provided with two papillae while the ventro-lateral lips are provided with one small papillae. The inter-labia are small and conical. The oesophagus is cylindrical ending with small ventriculus and narrow ventricular appendix.

Male: It measures 18-53 (40.3) $\mathrm{mm}$ long and 0.5-1 $\mathrm{mm}$ wide. The dorsal lip measure $0.16 \mathrm{~mm}$ long and $0.16-0.17 \mathrm{~mm}$ wide while the ventrolateral one measure $0.14-0.15 \mathrm{~mm}$ long and $0.15-0.17 \mathrm{~mm}$ wide. The oesophagus measures $2.4-3 \mathrm{~mm}$ long The ventriculus is broader than long measuring $0.21 \times 0.18 \mathrm{~mm}$ while, ventricular appendix measures 0.27-1.14 $\mathrm{mm}$. The nerve ring is $0.5 \mathrm{~mm}$ from the anterior extremity. The excretory pore is slightly posterior to the level of nerve ring. The spicules are alate, equal and measure1.9-3.3 $\mathrm{mm}$ long.

Female: It measures 28-63 (49.0) $\mathrm{mm}$ long and 0.85-1.5 mm wide. The dorsal lip measure $0.19-23 \mathrm{~mm}$ long and $0.2-0.15 \mathrm{~mm}$ wide while the ventro-lateral one measure $0.21-0.22 \mathrm{~mm}$ long and $0.22-0.25 \mathrm{~mm}$ wide. The oesophagus measures 3.2-4.3 mm long. The ventriculus and ventricular appendix measure $0.27-0.23 \times 0.24-0.29 \mathrm{~mm}$ and $0.9-1.2 \mathrm{~mm}$ long respectively. The nerve ring is $0.6 \mathrm{~mm}$ from the anterior extremity. The vulva open at the anterior third and without lips. Tail is conical, measuring 0.27-0.42 $\mathrm{mm}$ and ends with small spinosed process.

2-Hysterothylacium geschei (Torres et al., 1998) (Fig. 7-9)

- Host : Red Mullet (Mullus barbatus)

- Habitat : intestine 
Description of female : The body of the adult worm is tapering at both ends measuring 32-73 (45.8) $\mathrm{mm}$ long and 0.7-1.5(1.0) $\mathrm{mm}$ wide. The head is rounded with two cephalic process. The dorsal lip which measures $0.15-0.2 \times 0.14-0.19 \mathrm{~mm}$ is slightly wider than the sub-ventral ones which measure $0.15-0.18 \times 0.13-0.15 \mathrm{~mm}$. The inter-labia are longer than wide. The oesophagus measure 3.3-7.6 m long. The ventriculus is slightly wider than narrow and measure $0.24-0.35 \times 0.25-0.45 \mathrm{~mm}$. The ventricular appendix measure 1.2-2.2 mm long. The vulva open at the anterior third of the body. Tail is provided with numerous small spine and measures $0.22-0.24 \mathrm{~mm}$ long.

\section{3-Hysterothylacium sp. (Fig. 10-12)}

-Host : :Red Mullet (Mullus barbatus)

-Habitat : intestine

Description of female: Its body is cylindrical measuring $50 \mathrm{~mm}$ long. The head is rounded and provided with three pairs of ridges. Lips are small and rounded. The oesophagus measure 1.3-2.0 mm long. The ventriculus is nearly spherical measuring $0.19 \times 0.18 \mathrm{~mm}$ while, the ventricular appendix is short and measures $0.27 \mathrm{~mm}$ long. Tail is tapered,provided with numerous sub-terminal spines and measures $0.2-0.22 \mathrm{~mm}$ long.

4-Hysterothylacium sp. larva. (Fig.13-14)

- Host : Red Mullet (Mullus barbatus)

- Habitat : intestine

Description: It measures $8-13 \mathrm{~mm}$ long. The head is provided with two papillae at its anterior extremity. The oesophagus is long and thin measuring 0.6-1.0 mm long. The ventriculus is small and longer than wide while, the ventricular appendix is very long measuring 0.27-0.56 $\mathrm{mm}$. Nerve ring is lying at the junction of the first and second thirds of oesophagus. The excretory pore is slightly posterior to nerve ring. Tail is short, conical,without spine and measures 0.11-0.115 mm. 
List of abbreviations:L(lips); N(Nerve ring);C.p Cephalic process; (papillae);R(ridges);E(Excretory pore);Oe(oesophagus);V (Ventriculus); V.a (Ventricular appendix);I.c (intestinal caecum);S (spine);Sp (Spicule); A (anal opening).

\section{LEGEND FIGURES}

Fig. 1-3: Goezia spinulosa 1,2- nterior end (x400) 3-Male caudal end $(\mathrm{x} 400)$

Fig. 4 - 6: Hysterothylacium 4-Anterior end (x40) 5-Female reliquens

6- Male caudal end tail(x40) (x40)

Fig.7-9:Hysterothylacium geschei.

Fig. 10-12: Hysterothylacium $s p$.
7-Anterior end (x40) 8- Female tail 9-Female tail $(\mathrm{x} 100) \quad(\mathrm{x} 40)$

10- Anterior end (x40) 11- Female tail 12- Female tail $(\mathrm{x} 100) \quad(\mathrm{x} 40)$

Fig.13-14: Hysterothylacium 13-Anterior end(x100) 14- tail (x100) sp. larvae 


\section{Gastro-Intestinal Nematodes Of Some Marine Fishes At Port ...}
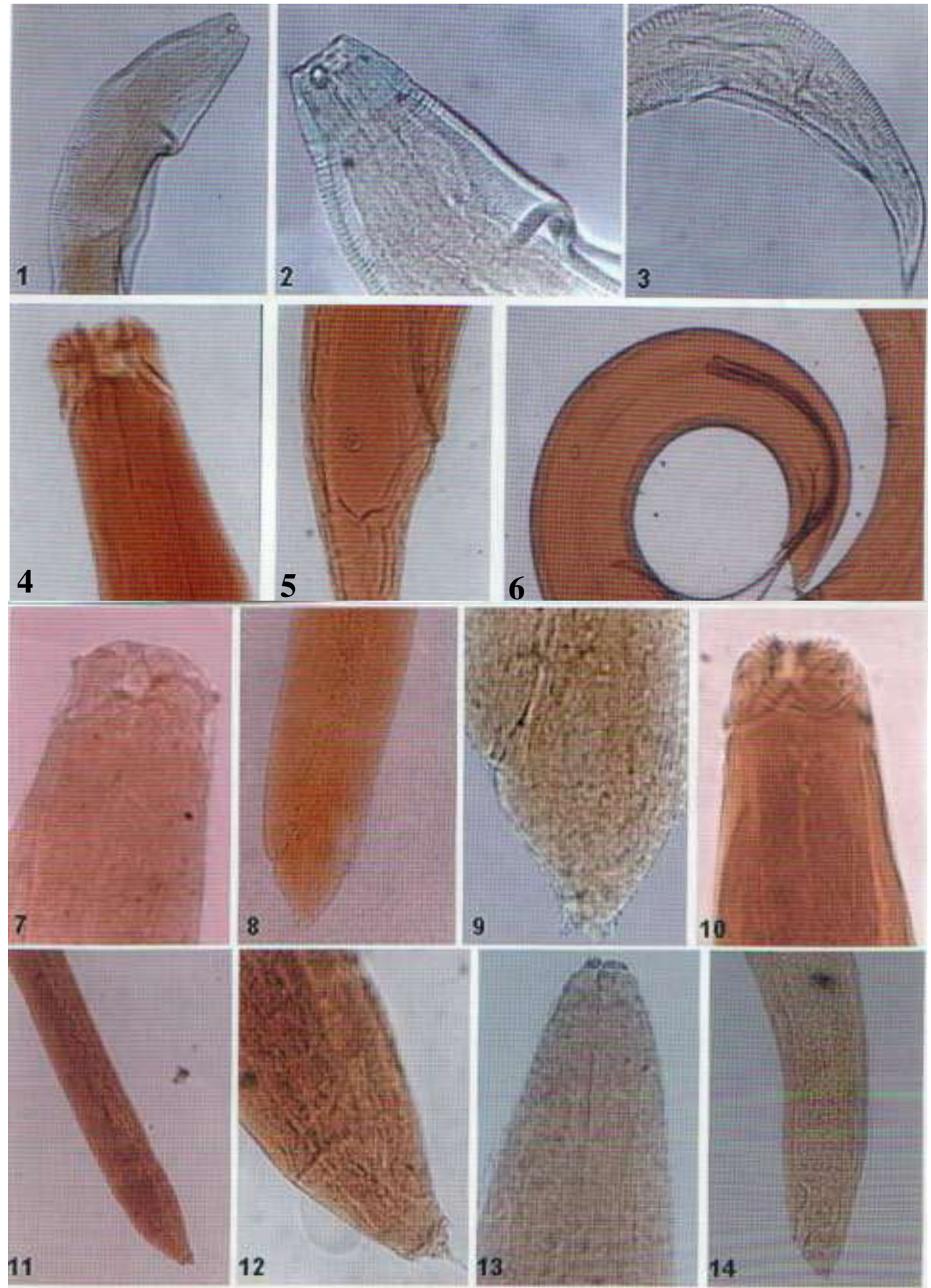

$\overline{\text { Kafr El-Sheikh Vet. Med. J. Vol. } 2 \text { No. } 1 \text { (2004) }}$ 
Nosseur M. El-Sayed., et.al.

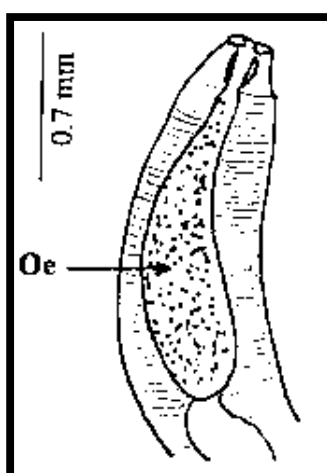

Fig. 1



Fing 2

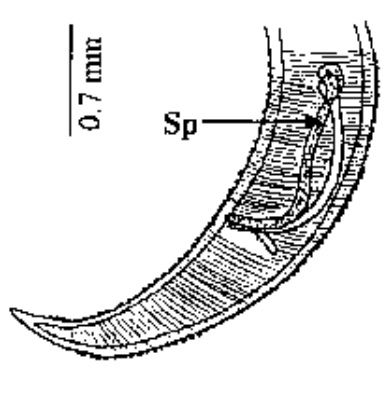

Fig. 3

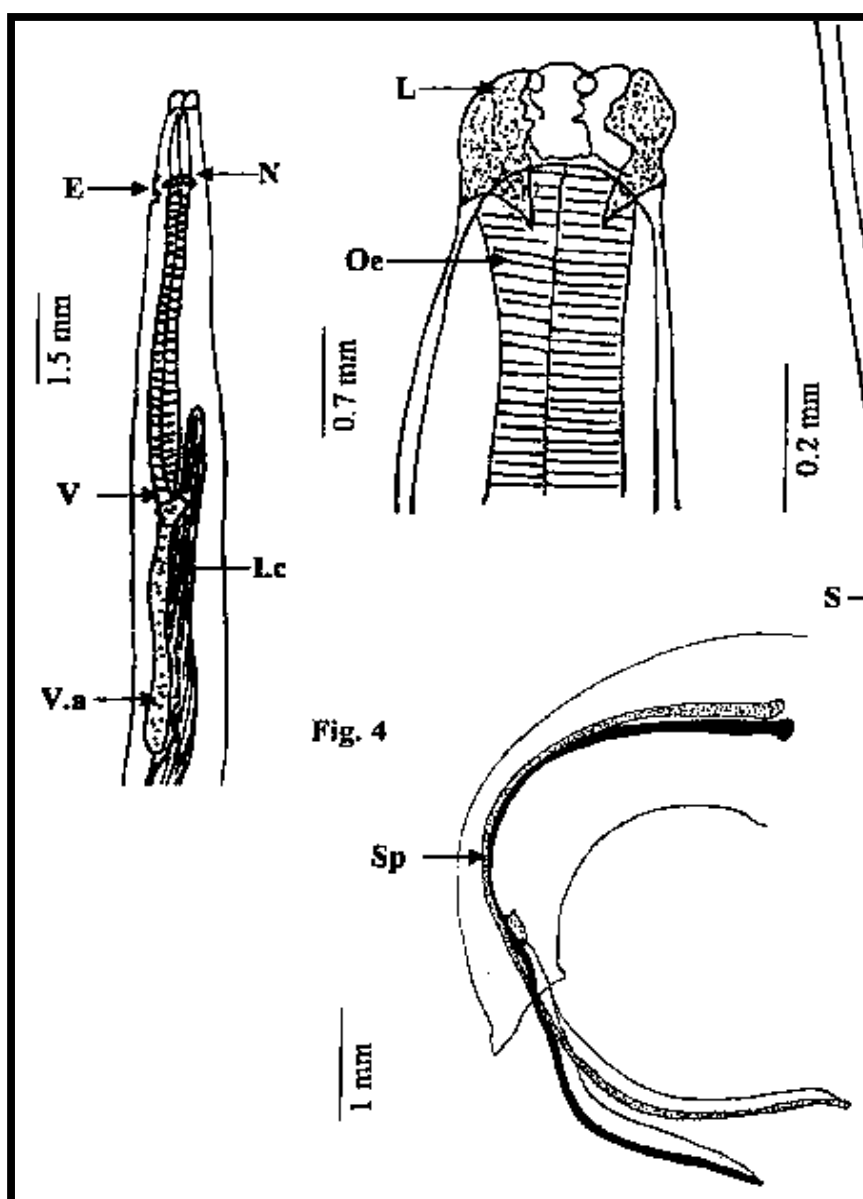

Fig. 6

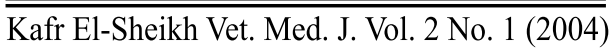




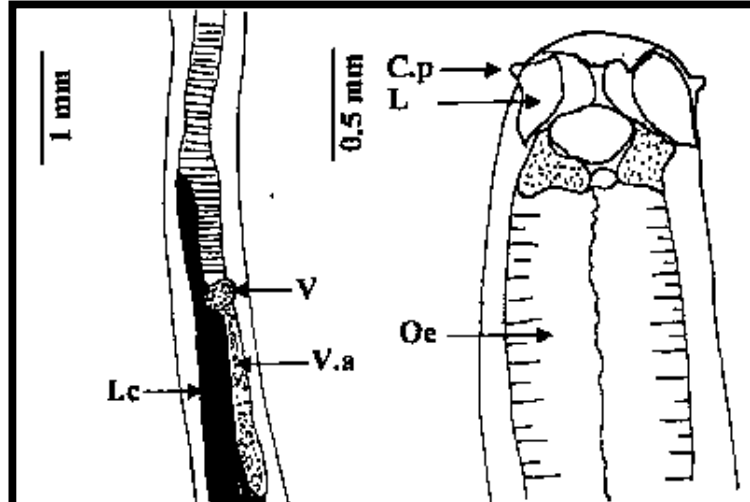

Fig. 7
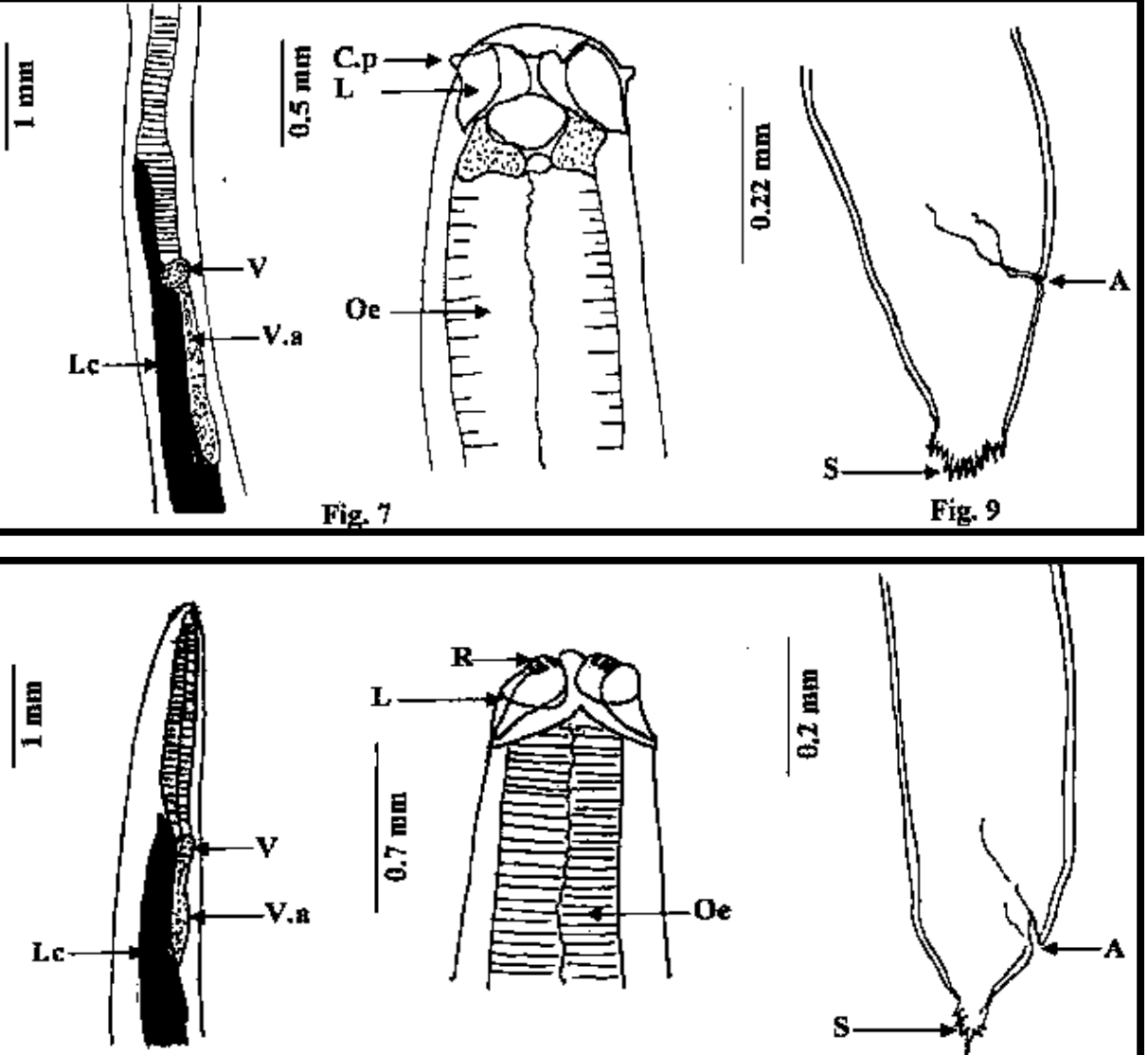

Fig. 10



Fig. 12
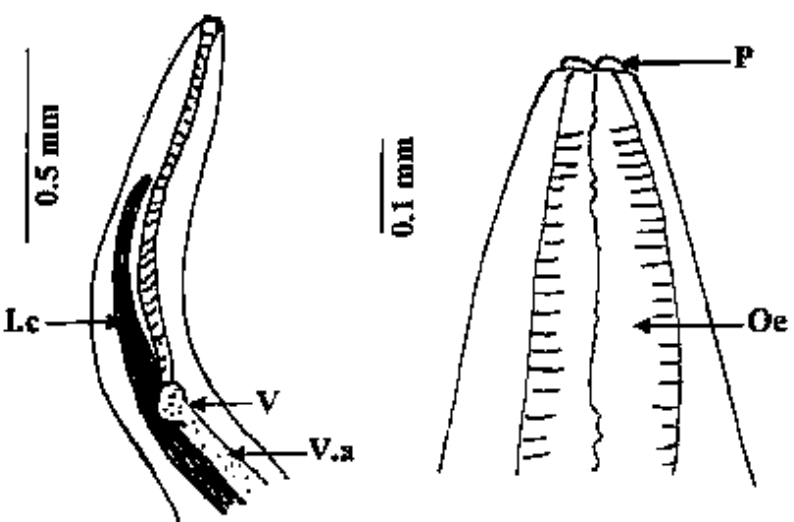

Fig. 13

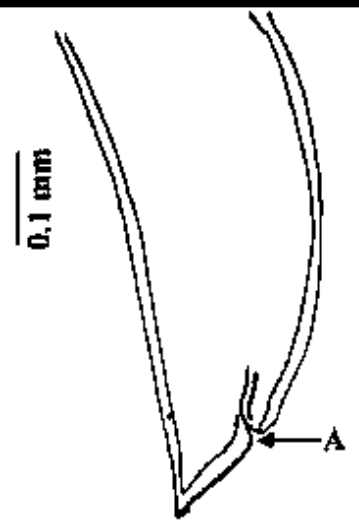

Fig. 14

$\overline{\overline{\text { Kafr El-Sheikh Vet. Med. J. Vol. } 2 \text { No. } 1 \text { (2004) }}}$ 


\section{DISCUSSION}

A survey of gasterointestinal nematodes in marine fishes from the local fish market in Port Said city was done during the period from October 2002 till September,2003. Nematodes of family Anisakidae were the most prevalent parasites.

The present study revealed that ten $(5.26 \%)$ out of 190 examined fishes at Port Said city were infected with nematode parasites. Bull head (Cottus gobio) and Red Mullet (Mullus barbatus) were infected with nematodes (3.12\% and $14.3 \%$ respectively)while, Dusky perch (Epinephelus gigas) and Sea Bass (Morone laborax) were free from parasitic infection. The total prevalence rate was higher than that reported by Raef, (1994)for nematode larvae in marine fish.It was lower than that mentioned by Sey \& petter, (1997) for Ascaridiod larvae in Kuwuaiti food fish.The prevalence of round worms was higher in Bull head (Cottus gobio) and Red Mullet (Mullus barbatus) and lower in Dusky perch (Epinephelus gigas) and Sea Bass (Morone laborax) than that reported by Raef, (1994). The low prevalence of nematode parasites in the present study may be attributed to high salinity of sea water which unfavourable media for the development of infective larvae.

Five species of nematodes; Goezia spinulosa, Hysterothylacium reliquens, Hysterothylacium geschei, Hysterothylacium sp. and Hysterothylacium sp. larva belonged to family Anisakidae were detected in the present study.

There are several species belonged to genus Goezia, G.braziliensis G. brevicaeca (Moravec et al.,1994), G.anguillae (Lebre et Petter, 1983) and G spinulosa (Diesing, 1839). G.ascaroides (Goeze, 1728). The present species which characterized by presence of conspicious plicated ring possessing posteriorly directed spine, inconspicious caudal papillae and equal spicules was morphologically identical to Goezia spinulosa described by Baylis, (1927). 
There are about 55 species of genus Hysterothylacium have been described from the estuarine and freshwater fishes (Bruce et al., 1994; Moravec et al., 1997). The present work revealed four species of Hysterothylacium (H. reliquens, H. geschei, Hysterothylacium sp. and Hysterothylacium sp. larva).

Hysterothylacium reliquens which recovered from intestine of Mullus barbatus was characterized by presence of equal alate spicules at male caudal end and conical spinosed tail in female.The measurement and main characteristic features including lips, oesophagus, ventricular appendix, spicule and female tail were identical to that described by Norris \&Overstreet, (1975); Deardorff \& Overstreet, (1981) and Petter\& Cabaret, (1995).

Hysterothylacium geschei was recoverd from intestine of Mullus barbatus. The presence of two cephalic process at its anterior end and spines at the end of female tail; length of oesophagus and ventricular appendix were similar to that described by Torres et al., (1998). It should be differentiated from H.gadi described by Raef \& Abdel whaab, (1999) by presence of cephalic process and short tail.

Hysterothylacium sp. was detected from intestine of Mullus barbatus. This species differ from other species of Hysterothylacium in having of three pairs of ridges at its anterior extermity and tapered tail carrying sub-terminal spines.

Hysterothylacium sp.larva was recovered from intestine of Mullus barbatus This larva characterized by presence of two papillae at anterior extremity and conical tail.Their dimension and shape of tail were similar to Hysterothylacium sp. larvae C china type I of Sun et al.,(1992) Hysterothylacium sp.larvae type KF of Petter \& Sey,((1997) and Contracaecum larvae B from red sea (Shiraki 1974). 


\section{REFERENCES}

- Abdel Rhaman, A.E.M. (1995): Studies on the helminth parasites of some fishes from the Mediterranean sea. M. Sc.thesis,Fac.Sci., Zagazig University.

- Baylis,H.A.(1927): Some parasitic worms from Arapaima gigas (Teleostean fish)with description of Philometra senticosa n.sp. (Filariodea).Parasitology, 1:35- 49

- Bruce, N .L. ;Adlard, R.D and Cannon, L.R.G (1994): Synoptic checklist of ascaridoid parasites (Nematoda) from fish hosts. Invertebrate Taxonomy 8: 583-674.

- Deardorff, T and Overstreat, R.M.(1981): Review of Hysterothylacium and Iheringascaris (both previously =Thynnascaris ) (Nematoda: Anisakidae) from the northen Gulf of Mexico. Proceeding of the biological Society of Washington 93:1035-1079.

- Elmer, R.N.;Glenn, A.N.; Gerhard, A.S. and Austin, J.M. (1989): Paras-itology "The biology of animal parasites" $6^{\text {th }}$ ed. Lea \&Febiger.Philadephia-London.

- Eslami,A.and Mokhayer,B.(1977): Nematode larvae of medical importance found in market fish in Iran. Medical Journal $8: 345-$ 348.

- Eslami, A. and Mokhayer,B. ( 1994 ): Nematode larvae of medical import-ance found in market fish in Iran. Archive of the Faculty of veterinary medicine, Teheran University $6: 120-123$.

- Harford,W.and Arlene, J.(1994): Parasitic worms of fish.Taylor \& Francis Ltd. London

- Kabata,Z.(1985): Parasites and diseases of fish.Culture in the tropics Taylor \& Francis Ltd. London and Philadelphia. 
- Lakshmi, I.R.; Rao, K.H. and Shyamasundary, K. (1990): New record of Porrocaecum and Hysterothylacium sp. (Nematoda; Anisakidae) from fishes of Bay of Bengal. Bol. Chil. Parasitol. 45(34 :91-93.

- Lebre, C. et Petter, A.J. (1983): Deux nouvelles especes d ‘ Ascarides (Nematoda) parasites de poisons Teleosteen Raphidascaris mediterraneus n.sp et Goezia anguillae n.sp. complement de description Cucullanus micropapillatus Tornquist, 1931 (Nematoda, Cucllanidae ). Bull. Mus.Natn Hist.Nat. Paris Ser 4e,5, Ahmed, 2: 491-505.

- Lymbery,A..J. ;Doupe,R.G.;Munshi,M.A. and Wong ,T. (2002): Larvae of contracaecum $s p$. among inshore fish species of Southwestern Australia. Dis. Aquat. Organ. 51(2) :157-179.

- Mahmoud, N.E. (1990): Some studies on the helminth parasites of marine water fishes in Suez canal area. M.V.Sc. thesis (Parasitology), Fac. Vet. Med. Suez canal University

- Mattiucci,s.;Cianchi.R.; Nascetti,G.; Paggi,L.; Sardella,N.; Timi,J.; Webb, S.C.;Bastida, R.; Rodriguez, D. and Bullini, L. (2003): Genetic evidence for two sibling species within Contracaecum ormorhini Johnston \& Mawson, 1941 (Nematoda :Anisakidae) from Otariid seals of boreal and austral regions. Syst. Parasitol., 54 (1) : 13-23

- Moravec,F (1994): Parasitic nematodes of fresh water fishes of Europe. Kluwer Academic publishers Dordrecht, Netherland.

- Moravec, F.; Kohn, A. and Fernandes, B. M. ( 1994): Two new species of the genus Goezia, G. brasiliensis sp. n. and G. brevicaeca sp. n. (Nematoda: Anisakidae), from freshwater fishes in Brazil. Folia Parasitol 41(4):271-8.

- Moravec, F.; Urawa, S. and Coria, C.O.( 1997): Hysterothylacium patag-onense $n$. sp. (Nematoda: Anisakidae) from freshwater fishes in Patagonia, Argentina, with a key to the species of 
Hysterothylacium in American fresh-water fishes. Syst. Parasitol 36: 31-38.

- Navone, G.T., Etchegoin, J.A. and Cremonte, F. (2000): Contracaecum multipapillatum (Nematoda: Anisakidae) from Egretta alba(Aves: Ardeidae) and comments on other species of this genus in Argentina. J. Parasitol., 86: 807-810.

- Norris,D.E. and Overstreet, R.M. (1975): Thynnascaris reliquens sp.n. and T.babena(Linton,1900)(Nematoda : Ascaridoidea)from fishes in the northern Gulf of Mexico and eastern U.S. Seabord. J. Parasitology 61:330-336.

- Parukhin,A.M.(1976): Parasitic worms in food fishes of the Southern Seas. Naukova Dumka, Kief.

- Parukhin, A.M. (1989): Parasitic worms in bottom fishes of the Southern Seas. Naukova Dumka, Kief.

- Petter,A. J. and Cabaret,J.(1995): Ascaridoid nematodes of teleostean fishes from the eastern North Atlantic and sea of the North of Europe.Parasite 2 (2s):217-230

- Petter, $O$. and Sey, A.J. (1997): Nematode parasites of marine fishes from Kuwait, with a description of Cucullanus trachinto n.sp. from Trachintus blochi. Zoosystema19 (1) :35-59

- Raef, A.M.( (1990): Some study on the helminth parasites some maine fish. M.V.Sc.. thesis (Parasitology ), Fac. Vet. Med. Zagazig Univ.

- Raef, A.M.( 1994): Role of marine fish in transmission of some parasites to animals and birds. Ph.D. thesis (Parasitology), Fac. Vet. Med. Zagazig Univ.

- Raef, A.M.and Abel Wahab,T.M.(1999): Ascaridiod nematodes of Marine fish at Port Said Governorate. Alex. J. Vet. Science 15 (3) : 533-540. 
- Sey, O. and Petter, A.J.(1997): Nincidence of Ascaridoid larvae in Kuwaiti food fishes.Southeast Asian J.Trop.Med.Public Health., 28 suppl 1:168-172.

- Shiraki, T. (1974): Larval nematodes of family Anisakidae (Nematoda) in the northern sea of Japan - as a causative agent of eosinophilic phlegmone or granuloma in the human gastro-intestinal tract . Acta Medica et Biologica 22: 57-98

- Sun, S.; Koyama,T. and Kagei, N. (1992): Morphological and taxanomical studies on Anisakidae larvae found in marine fishes of China.II.Gulf of Tong King. Chinese Journal of Parasitology and Parasitic diseases 10:108-112.

- Torres, P.; Andrade, P. and Silva, R. (1998): On a new species of Hystero-thylacium (Nematoda :Anisakidae) from Cauque mauleanum (Pisces: Ather-inidae) by brightfield and scanning electron microscope. Mem.Inst. Oswaldo Cruz. 93 (6); 745-752. 